\title{
Litterfall and Nutrient Input in a Degraded Area
}

\author{
Rômulo Guimarães Giácomo ${ }^{1}$, Marlene Cristina Alves ${ }^{1}$, Rodrigo Camara ${ }^{2}$, \\ Marcos Gervasio Pereira ${ }^{2}$, Otton Garcia de Arruda ${ }^{1}$, Sebastião Nilce Souto ${ }^{1}$, \\ Mário Luis Teixeira de Moraes ${ }^{1}$

\begin{abstract}
${ }^{1}$ Universidade Estadual Paulista "Julio de Mesquita Filho" - UNESP, Ilha Solteira/SP, Brazil
${ }^{2}$ Universidade Federal Rural do Rio de Janeiro - UFRRJ, Seropédica/RJ, Brazil
\end{abstract}

\begin{abstract}
This study aimed to test the effects of fertilization with organic compost from industrial production of pulp on the litterfall and nutrient input of monospecific plantations in a loan area. The treatments consisted of three doses of the organic compost $\mathrm{D}_{10}, \mathrm{D}_{15}$ and $\mathrm{D}_{20}\left(10,15\right.$ and $20 \mathrm{Mg} \mathrm{ha}^{-1}$, respectively), mineral conventional fertilization $\left(\mathrm{D}_{\mathrm{AM}}\right)$ and no fertilization $\left(\mathrm{D}_{0}\right)$ in land plots $(\mathrm{N}=4 /$ treatment/species; $15 \times 12 \mathrm{~m})$. Litterfall was monthly collected by two traps $\left(0.72 \mathrm{~m}^{2} / \mathrm{plot}\right)$ and sorted out into leaves, twigs, seeds, flowers, fruits and others. We determined the input of nitrogen, phosphorous and potassium. There were no differences among the treatments and between species in terms of total annual litterfall. The higher nutrient input was obtained by $\mathrm{D}_{\mathrm{AM}}$, followed by $\mathrm{D}_{10}$, in both plantations. The annual nutrient input was higher for the litterfall on the E. urograndis plantation.
\end{abstract}

Keywords: Eucalyptus urograndis, Mabea fistulifera, nutrient cycling. 


\section{INTRODUCTION}

Removal of vegetation and topsoil in loan areas inhibits natural regeneration as it eliminates the seed bank, seedlings, seed rain, and thus the possibility of regrowth (Alves \& Souza, 2011). In these cases, recovery of the ecosystem can be extremely slow or may not even occur spontaneously. Thus, planting forest species allows for the recovery of the soil's physical, chemical and biological attributes in degraded areas (Valcarcel \& Silva, 2000). This is due to the fact that the tree canopy provides mechanical protection against erosive agents and favors soil restructuring, as does deciduous material, which also contributes to nutrient cycling (Heaney \& Proctor, 1989; Parrotta, 1995; Li et al., 2014).

The return of mineral elements through litter decomposition and mineralization is particularly relevant where soils are chemically poor, like most tropical forest ecosystems (Vitousek \& Sanford, 1986; Martius et al., 2004). As a result, litter influences the plant community structure in these ecosystems (Facelli \& Pickett, 1991; Molofsky \& Augspurger, 1992). Litter is still considered a bio-indicator of ecosystem functioning, as environmental changes influence litterfall (Martins \& Rodrigues, 1999; Klumpp, 2001). This is based on the fact that even within the same type of vegetation, litterfall responds to the degree of environmental degradation, successional stage, latitude, altitude, temperature, rainfall, winds, herbivores, soil water and nutrient availability (Portes et al., 1996; Martins \& Rodrigues, 1999; Figueiredo et al., 2003).

Likewise, the litter nutrient content also depends on the edaphic and climatic conditions, as well as on plant species, plant tissue and the mineral element (Ferraz, 2009). Thus, studies focused on litterfall and nutrients input contribute to the knowledge of its potential for the recovery of soil attributes in degraded areas (Souza \& Davide, 2001). In these areas, certain types of industrial waste can also improve the chemical attributes of the soil in forest plantations, such as the ones obtained from the production of pulp and paper (Bellote et al., 1998). However, depending on the applied dose, this practice can also produce negative effects, such as higher availability of sodium in the soil (Maciel et al., 2015).

As a result, it is important to investigate the suitability of pulp residue doses in forest plantations for land recovery. This study aimed to test the effect of soil fertilization with organic compost from industrial pulp production on litterfall and nutrient input in monospecific plantations established on degraded soil. We hypothesized that fertilization with this organic compound increases litter production and nutrient input compared to the control and mineral fertilization in monospecific plantations of Mabea fistulifera Mart. and Eucalyptus urograndis at a loan area in Selvíria, Mato Grosso do Sul, Brazil.

\section{MATERIAL AND METHODS}

The study area belongs to Universidade Estadual Paulista (UNESP) and it is located at coordinates $20^{\circ} 22^{\prime} \mathrm{S}$ and $51^{\circ} 22^{\prime} \mathrm{W}$, in Selvíria, state of Mato Grosso do Sul, Brazil, at an altitude of $327 \mathrm{~m}$ above sea level (Colodro, 2005). The climate type is Aw (tropical humid climate, with rainy season in the summer and dry in winter), according to Köppen (1948). According to the meteorological data obtained for the period between January 2011 and January 2012 from the website of São Paulo State University (UNESP, 2016), the total annual precipitation is $1,695.6 \mathrm{~mm}$, the average monthly temperature is $24.7^{\circ} \mathrm{C}$ and the relative monthly humidity ranges from $70 \%$ to $80 \%$. The rainy season extends from October to April and the wettest months are January, February and March (Figure 1). The dry season extends from May to September, and the driest months are July, August and September. The relief is plain or flat, and the soil is Oxisoil (EMBRAPA, 2006). The original vegetation is Cerrado (savanna).

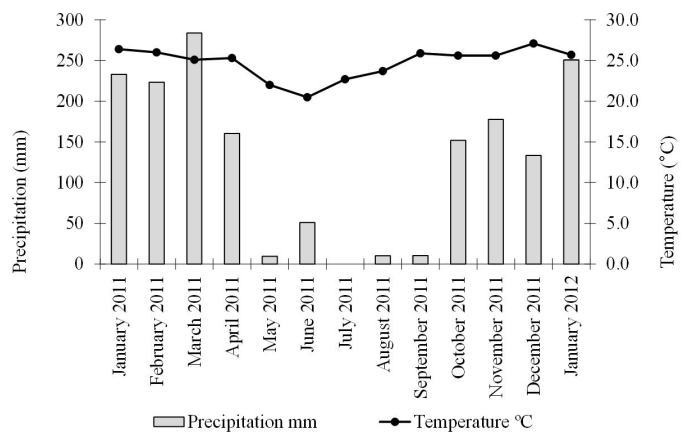

Figure 1. Monthly average precipitation and temperature in Ilha Solteira, approximately $11 \mathrm{Km}$ away from Selvíria, MS. Source: UNESP (2016). 
A loan area was selected for the experiment, in which a soil layer with $8.60 \mathrm{~m}$ average thickness was removed in 1969 for earthmoving and foundation of the Hydroelectric Plant of Ilha Solteira, in the state of São Paulo (Alves \& Souza, 2011). The remaining $\mathrm{B}$ horizon is still exposed, and its physical and chemical characteristics were obtained by Giácomo (2013) before the experiment was performed. According to this author, the results were $(0-0.40 \mathrm{~m}): \mathrm{pH}\left(\mathrm{CaCl}_{2}\right)=5.6$; $\mathrm{P}=3 \mathrm{mg} \mathrm{dm}^{-3} ; \mathrm{K}=1.2 \mathrm{mg} \mathrm{dm}^{-3} ; \mathrm{Ca}^{2+}=8 \mathrm{mmol}_{\mathrm{c}} \mathrm{dm}^{-3}$; $\mathrm{Mg}^{2+}=7 \mathrm{mmol}_{\mathrm{c}} \mathrm{dm}^{-3} ; \mathrm{H}^{+}+\mathrm{Al}^{3+}=14 \mathrm{mmol}_{\mathrm{c}} \mathrm{dm}^{-3}$; organic matter $=10 \mathrm{~g} \mathrm{dm}^{-3}$; sandy clay loam texture; bulk density $=1.63 \mathrm{~kg} \mathrm{dm}^{-3}$. Due to the high bulk density of the soil, it was necessary to perform soil unpacking in the whole area, in December 2009 (in the depth of $0.40 \mathrm{~m}$ ), and in the row, in February 2010 (until $0.50 \mathrm{~m}$ ).

After soil unpacking, we established monospecific plantations of Eucalyptus urograndis and the native Cerrado species Mabea fistulifera in four plots of $15 \mathrm{~m}$ x $60 \mathrm{~m}$ each per forest species, in February 2010. The experimental design was a completely randomized block, in a split-plot arrangement, with four replicates (plots). We planted 200 seedlings of Eucalyptus urograndis or Mabea fistulifera per plot in rows. Spacing was $3.0 \mathrm{~m}$ between rows and $1.5 \mathrm{~m}$ between trees in each row. The plots were spaced $2.0 \mathrm{~m}$ apart from one another, and the blocks, $3.0 \mathrm{~m}$ from one another.

We considered as useful three central rows (18 plants each) in each treatment, avoiding the edges. The plots were divided into subplots ( $15 \mathrm{~m} \mathrm{x} 12 \mathrm{~m}$ ), where we considered five treatments: (1) $\mathrm{D}_{0}$ (control or no fertilization); (2) $\mathrm{D}_{\mathrm{AM}}$ (mineral fertilization according to the crop's needs); (3) $\mathrm{D}_{10}$ (organic fertilization with $10 \mathrm{Mg} \mathrm{ha}^{-1}$ of the industrial residue from pulp production, according to the crop's needs); (4) $\mathrm{D}_{15}$ (15 $\mathrm{Mg} \mathrm{ha}^{-1}$ of industrial residue); (5) $\mathrm{D}_{20}$ (20 $\mathrm{Mg} \mathrm{ha}^{-1}$ of industrial residue). These treatments were selected according to the results of the chemical soil analyses performed by Giácomo (2013).

All of the fertilizers were manually distributed in the row, with its subsequent incorporation into the soil by means of light harrowing. The seedlings of Eucalyptus urograndis and Mabea fistulifera were produced from seeds and donated by the Fibria company and Companhia Energética de São Paulo (CESP), respectively. The industrial residue was obtained by the Kraft method and donated by the Central de Compostagem of Grupo Ambitec. This material consisted of a mixture of dregs (dark-colored sediment), grits (yellowish granules), lime mud, ash and other waste, which underwent a process of composting for 30 days. During this process, the organic compound was exposed in windrows and periodically revolved mechanically. According to Giácomo (2013), the organic compound presented: $\mathrm{pH}\left(\mathrm{CaCl}_{2}\right)=9.5$; organic carbon $=186 \mathrm{~g} \mathrm{~kg}^{-1}$; $\mathrm{N}=6.3 \mathrm{~g} \mathrm{~kg}^{-1} ; \mathrm{C} / \mathrm{N}=6.3 ; \mathrm{P}=2.4 \mathrm{~g} \mathrm{~kg}^{-1} ; \mathrm{K}=5.9 \mathrm{~g} \mathrm{~kg}^{-1}$; $\mathrm{Ca}=86.9 \mathrm{~g} \mathrm{~kg}^{-1} ; \mathrm{Mg}=3.8 \mathrm{~g} \mathrm{~kg}^{-1} ; \mathrm{S}=1.8 \mathrm{~g} \mathrm{~kg}^{-1}$; $\mathrm{Na}=1.35 \mathrm{~g} \mathrm{~kg}^{-1} ; \mathrm{B}=30.3 \mathrm{mg} \mathrm{kg}^{-1} ; \mathrm{Cu}=14.3 \mathrm{mg} \mathrm{kg}^{-1}$; $\mathrm{Fe}=5458 \mathrm{mg} \mathrm{kg}^{-1} ; \mathrm{Mn}=845 \mathrm{mg} \mathrm{kg}^{-1} ; \mathrm{Zn}=27.9 \mathrm{mg} \mathrm{kg}^{-1}$.

The litterfall was evaluated by means of two traps installed in the central row of each treatment. The litter traps were constructed with $1.0 \mathrm{~mm}$ nylon mesh measuring $0.80 \mathrm{~m}$ x $0.80 \mathrm{~m}$ mounted on a frame of four PVC tubes suspended $0.20 \mathrm{~m}$ above the soil surface and attached to wooden stakes. Litter samples were collected monthly from February 2011 to January 2012, placed in paper, and transported to the laboratory. The material was manually separated into 1) leaves, 2) branches, 3) flowers, 4) fruits, 5) seeds and 6) unidentified material (others). Each sample was oven-dried at $65^{\circ} \mathrm{C}$ for 72 hours and subsequently weighed. Litterfall biomass was estimated according to the equation $\mathrm{AL}=\frac{(\Sigma \mathrm{ML} \times 10,000)}{\mathrm{TA}}($ Lopes et al., 2002), where: $\mathrm{AL}=$ annual average of litterfall $\left(\mathrm{kg} \mathrm{ha}^{-1} \mathrm{year}^{-1}\right)$; $\mathrm{ML}=$ monthly litterfall $\left(\mathrm{kg} \mathrm{ha}^{-1}\right.$ month $\left.^{-1}\right) ; \mathrm{TA}=$ trap area $\left(\mathrm{m}^{2}\right)$.

The litter samples were ground using a Wiley mill with a $1 \mathrm{~mm}$ mesh screen and subjected to sulfuric acid digestion in order to determine nutrient concentration (Tedesco et al., 1995). The nitrogen $(\mathrm{N})$ concentration was determined by means of steam distillation; phosphorus $(\mathrm{P})$, by colorimetry; and potassium $(\mathrm{K})$, by flame photometry. Thereafter, the contents of $\mathrm{N}, \mathrm{P}$ and $\mathrm{K}$ were determined by multiplying the biomass by the appropriate nutrient concentration.

The data were subjected to analysis of variance, assuming the existence of homogeneity of variance and normality of residuals. When averages were significant, they were compared by means of the Scott-Knott test with a level of significance of 5\%. For these analyses, the original data of litterfall and nutrient content was transformed by $\sqrt{\mathrm{x}}$, and we used SISVAR 5.1 software version (Ferreira, 2008). The Pearson correlation analysis 
was performed with the aim of identifying the influence of meteorological factors (precipitation, temperature) on total annual litterfall. A cluster analysis was also performed in order to identify possible correlations between fertilization treatments and annual litterfall (total and fractions) by using version $2.17 \mathrm{c}$ of the PAST software (Hammer et al., 2001). Thus, we obtained a dendrogram of distances by means of the complete linkage method and Euclidean distance. In the case of Eucalyptus urograndis planting, we only considered the results obtained from total annual litterfall, leaves, twigs and the fractions "other", since there was no production of reproductive structures (flowers, fruits and seeds) in this area.

\section{RESULTS AND DISCUSSION}

In the area, total annual litterfall ranged from 1.1 $\mathrm{Mg} \mathrm{ha}^{-1} \mathrm{yr}^{-1}\left(\mathrm{D}_{20}\right)$ to $2.6 \mathrm{Mg} \mathrm{ha}^{-1} \mathrm{yr}^{-1}\left(\mathrm{D}_{\mathrm{AM}}\right)$ in the Mabea fistulifera plantation, and from $0.9 \mathrm{Mg} \mathrm{ha}^{-1} \mathrm{yr}^{-1}$ $\left(\mathrm{D}_{0}\right)$ to $2.6 \mathrm{Mg} \mathrm{ha}^{-1} \mathrm{yr}^{-1}\left(\mathrm{D}_{\mathrm{AM}}\right)$ in the Eucalyptus grandis plantation (Table 1). The coefficient of variation values for total annual litterfall for comparison among fertilization treatments in the same species were considered medium (between 10\% and 20\%), and between species in the same fertilization treatment were considered high (between 20\% and 30\%), according to Pimentel-Gomes (1990). This fact probably contributed to the absence of significant differences in both comparisons. In contrast, fertilization with residue from industrial pulp production in the planting row resulted in higher litterfall for an Eucalyptus grandis plantation, compared to the mineral fertilizer in Mogi Guaçu, São Paulo (Ferreira et al., 2001).

Nevertheless, the cluster analysis indicated differences in the effect of the treatments on both forest plantations. In the case of Mabea fistulifera, we basically obtained two groups: group $1\left(\mathrm{D}_{0}, \mathrm{D}_{15}\right.$ and $\left.\mathrm{D}_{20}\right)$ and group $2\left(\mathrm{D}_{10}\right.$ and $\left.\mathrm{D}_{\mathrm{AM}}\right)$ (Figure 2 ). Treatments $\mathrm{D}_{15}$ and $\mathrm{D}_{20}$ showed high similarity because they correlated to each other at a distance of about $10 \%$. Both of them presented a distance of correlation of about $20 \%$ with $\mathrm{D}_{0}$. The $\mathrm{D}_{10}$ and $\mathrm{D}_{\mathrm{AM}}$ correlated to each other at a distance of more than $36 \%$. The correlation distance between group 1 and group 2 was about $60 \%$, which indicated low similarity between them.
Table 1. Total anual litterfall in Mabea fistulifera and Eucalyptus urograndis plantations, Selvíria, MS. $\mathrm{D}_{0}$ : control; $\mathrm{D}_{\mathrm{AM}}$ : mineral fertilizer; $\mathrm{D}_{10}, \mathrm{D}_{15}$ and $\mathrm{D}_{20}: 10,15$ and $20 \mathrm{Mg} \mathrm{ha}^{-1}$ of industrial residue from pulp production, respectively.

\begin{tabular}{|c|c|c|}
\hline Treatment & $\begin{array}{c}\text { Mabea } \\
\text { fistulifera }\end{array}$ & $\begin{array}{l}\text { Eucalyptus } \\
\text { urograndis }\end{array}$ \\
\hline & \multicolumn{2}{|c|}{$\mathrm{Mg} \mathrm{ha}^{-1} \mathrm{yr}^{-1}$} \\
\hline $\mathrm{D}_{0}$ & 1.3 & 0.9 \\
\hline $\mathrm{D}_{\mathrm{AM}}$ & 2.6 & 2.6 \\
\hline $\mathrm{D}_{10}$ & 1.5 & 1.9 \\
\hline $\mathrm{D}_{15}$ & 1.2 & 1.2 \\
\hline $\mathrm{D}_{20}$ & 1.1 & 1.5 \\
\hline $\mathrm{CV}^{1}(\%)$ & \multicolumn{2}{|c|}{18.3} \\
\hline $\mathrm{CV}^{2}(\%)$ & \multicolumn{2}{|c|}{27.8} \\
\hline
\end{tabular}

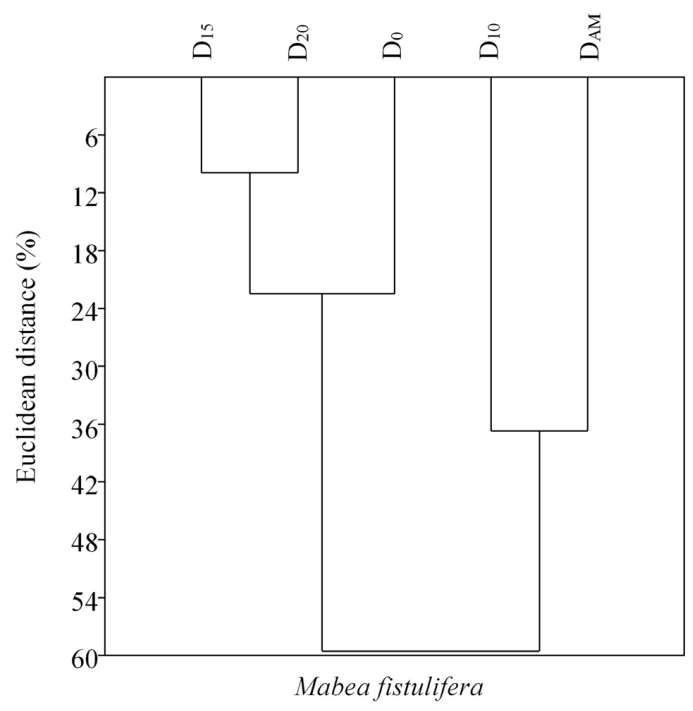

Figure 2. Distance dendrogram obtained by the mean of total annual litterfall and fractions in the Mabea fistulifera plantation, Selvíria, MS. $\mathrm{D}_{0}$ : control; $\mathrm{D}_{\mathrm{AM}}$ : mineral fertilizer; $\mathrm{D}_{10}, \mathrm{D}_{15}$ and $\mathrm{D}_{20}: 10,15$ and $20 \mathrm{Mg} \mathrm{ha}^{-1}$ of industrial residue from pulp production, respectively.

In the Eucalyptus urograndis plantation, we found that group 1 was formed by $\mathrm{D}_{0}$ and $\mathrm{D}_{10}$, and group 2 formed by $\mathrm{D}_{15}, \mathrm{D}_{20}$ and $\mathrm{D}_{\mathrm{AM}}$ (Figure 3 ). The $\mathrm{D}_{20}$ and $\mathrm{D}_{\mathrm{AM}}$ presented higher similarity (the distance of correlation between them was approximately $20 \%$ ). These treatments were correlated to $\mathrm{D}_{15}$ with a distance higher than $25 \%$. This distance of correlation was the same between $\mathrm{D}_{0}$ and $\mathrm{D}_{10}$. The low similarity between 
group 1 and group 2 was indicated by a correlation distance of about $80 \%$.

In the Mabea fistulifera plantation, the descending order of the fractions' relative participation in total litterfall was: leaves $>$ flowers $>$ fruits $>$ others $>$ branches $>$ seeds. The relative participation of leaves ranged from $77 \%\left(\mathrm{D}_{20}\right)$ to $82 \%\left(\mathrm{D}_{\mathrm{AM}}\right)$ in this plantation, with an average of $79 \%$ across all treatments. In the Eucalyptus grandis plantation, relative participation of the fractions followed the order: leaves $>$ branches $>$ others, and there was no participation of flowers, fruits and seeds. The relative participation of leaves in this plantation ranged from $81 \%\left(\mathrm{D}_{20}\right)$ to $87 \%\left(\mathrm{D}_{10}\right)$, with an average of $84 \%$ considering all the treatments.

The order of relative participation of litter fractions for the forest species were the same in all treatments. The high contribution of leaves, which commonly reaches $60 \%$ or more of total litter, was also observed in different tropical forest ecosystems (Cianciaruso et al., 2006; Giácomo et al., 2012; Schumacher et al., 2004, 2013). In the Mabea fistulifera plantation, the higher total litterfall occurred in the dry season (mainly between July and September) in all fertilization treatments (Figure 4). This pattern corroborated the results observed in an Amazon-Cerrado Transition Forest in Mato Grosso (Silva et al., 2009) and in different physiognomies of Cerrado (Cianciaruso et al., 2006; Giácomo et al., 2012). Higher litterfall influenced by higher leaf fall during the dry season occurs for many tree species as a strategy to overcome water deficit (Silva et al., 2014).

However, in the Eucalyptus grandis plantation, the higher total litterfall was observed during the rainy season until the beginning of the dry season (the period between December and April) (Figure 4). This same pattern occurred in a plantation of Eucalyptus urophylla $\mathrm{x}$ Eucalyptus globulus maidenii in Eldorado do Sul, Rio Grande do Sul (Schumacher et al., 2013). This fact is probably due to the mechanical action of heavy precipitation and winds of higher speed, which usually occur during the rainy season (Scheer et al., 2009). According to Guedes (2005), the production of leaf litter by eucalyptus would not be subject to a mechanism to minimize evapotranspiration during the dry season (winter), but to a higher internal retranslocation of nutrients from older to younger tissue, which influences higher litter production during the rainy season.

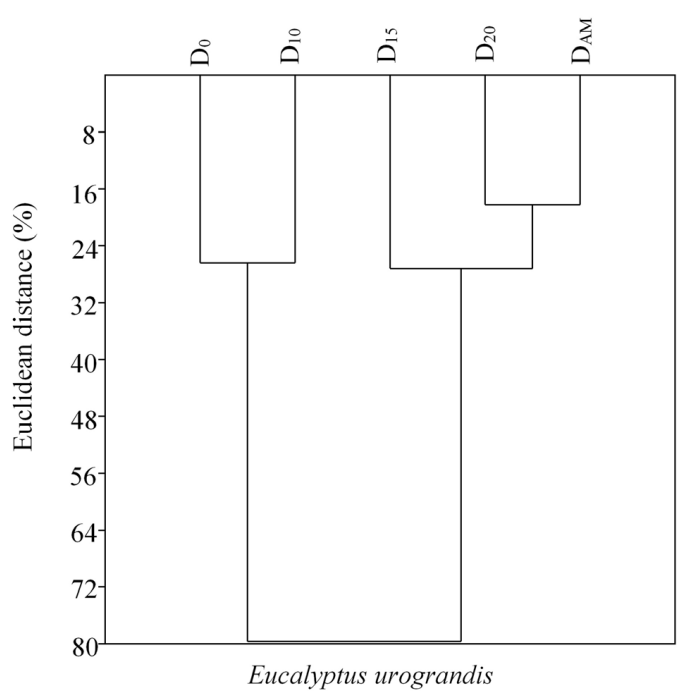

Figure 3. Distance dendrogram obtained by the mean of total annual litterfall and fractions in the Eucalyptus urograndis plantation, Selvíria, MS. $\mathrm{D}_{0}$ : control; $\mathrm{D}_{\mathrm{AM}}$ : mineral fertilizer; $\mathrm{D}_{10}, \mathrm{D}_{15}$ and $\mathrm{D}_{20}: 10,15$ and $20 \mathrm{Mg} \mathrm{ha}^{-1}$ of industrial residue from pulp production, respectively.
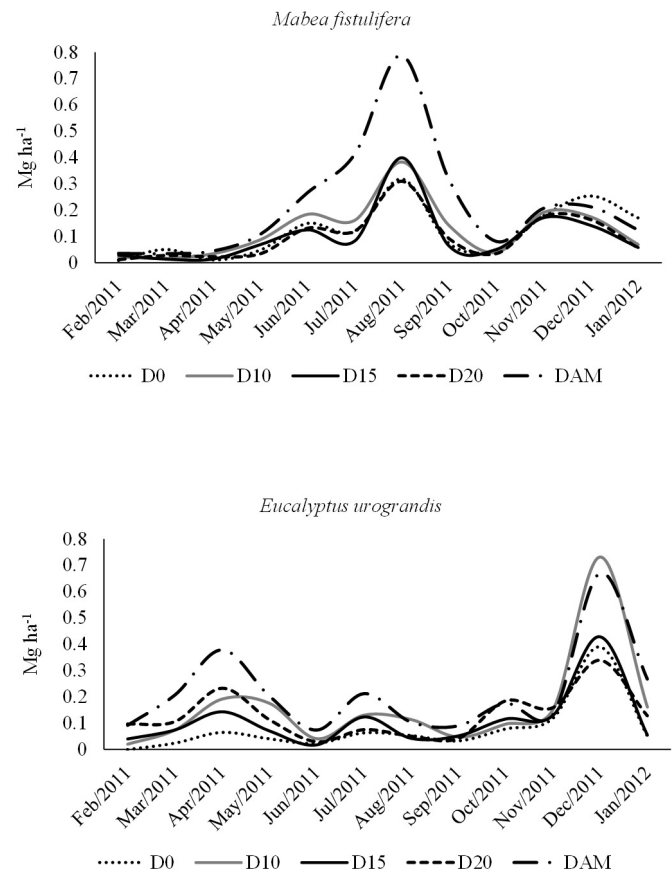

Figure 4. Monthly mean values of total litterfall in Mabea fistulifera and Eucalyptus urograndis plantations, Selvíria, MS. $\mathrm{D}_{0}$ : control; $\mathrm{D}_{\mathrm{AM}}$ : mineral fertilizer; $\mathrm{D}_{10}, \mathrm{D}_{15}$ and $\mathrm{D}_{20}: 10,15$ and $20 \mathrm{Mg} \mathrm{ha}^{-1}$ of industrial residue from pulp production, respectively. 
The Pearson correlation did not present significant values between total annual litterfall and precipitation, nor between total annual litterfall and temperature in both of the plantations and in all treatments (Table 2). The absence of significant correlation between litter production and meteorological factors, such as precipitation and temperature, was also observed in mesophytic forest and savanna (Cianciaruso et al., 2006; Giácomo et al., 2012). According to Scoriza \& Piña-Rodrigues (2014), the correlation between litterfall (total and its fractions) in tropical forest ecosystems and meteorological factors (precipitation and temperature) may not be significant in considering evaluation of litterfall during the same month.

Thus, a significant correlation is observed when the meteorological factors from the previous months are considered, and the influence of precipitation and temperature on litterfall may not be immediate (Scoriza \& Piña-Rodrigues, 2014). Besides meteorological factors, the phenological aspect of the tree species also influences litterfall seasonality (Souza \& Davide, 2001), which may account for the different patterns observed in relation to the forest species studied under the same climatic conditions.

In both plantations, the annual return of nutrients from total litterfall to the soil followed the order $\mathrm{N}>\mathrm{K}>\mathrm{P}$ (Table 3). This pattern corroborated the results obtained in monospecific plantations of Eucalyptus grandis Hill ex Maiden, Eucalyptus camaldulensis Dehn., and Eucalyptus pellita F. Muell in Campos dos Goytacazes, Rio de Janeiro (Zaia \& Gama-Rodrigues, 2004), mesophytic forest and savanna in the Ecological Station of Pirapitinga, Minas Gerais (Giácomo et al., 2012).

The input of $\mathrm{N}, \mathrm{P}$ and $\mathrm{K}$ ranged from $9.25\left(\mathrm{D}_{20}\right)$ to $20.30\left(\mathrm{D}_{\mathrm{AM}}\right)$, from $0.69\left(\mathrm{D}_{0}\right)$ to $1.40\left(\mathrm{D}_{\mathrm{AM}}\right)$ and from $5.35\left(\mathrm{D}_{20}\right)$ to $14.69\left(\mathrm{D}_{\mathrm{AM}}\right) \mathrm{kg} \mathrm{ha}^{-1} \mathrm{yr}^{-1}$, respectively, in the plantation of Mabea fistulifera (Table 3). In the

Table 2. Pearson correlation coefficients (r) between total annual litterfall and meteorological factors (precipitation and temperature) in Mabea fistulifera and Eucalyptus urograndis plantations, Selvíria, $\mathrm{MS}$. $\mathrm{D}_{0}$ : control; $\mathrm{D}_{\mathrm{AM}}$ : $\mathrm{mineral}$ fertilizer; $\mathrm{D}_{10}, \mathrm{D}_{15}$ and $\mathrm{D}_{20}: 10,15$ and $20 \mathrm{Mg} \mathrm{ha}^{-1}$ of industrial residue from pulp production, respectively.

\begin{tabular}{|c|c|c|c|c|}
\hline \multirow{2}{*}{ Treatment } & \multicolumn{2}{|c|}{ Mabea fistulifera } & \multicolumn{2}{|c|}{ Eucalyptus urograndis } \\
\hline & Precipitation (mm) & Temperature $\left({ }^{\circ} \mathrm{C}\right)$ & Precipitation (mm) & Temperature $\left({ }^{\circ} \mathrm{C}\right)$ \\
\hline $\mathrm{D}_{0}$ & $\mathrm{r}=-0.25^{\mathrm{ns}}$ & $\mathrm{r}=-0.03^{\mathrm{ns}}$ & $\mathrm{r}=0.03^{\text {ns }}$ & $\mathrm{r}=0.43^{\mathrm{ns}}$ \\
\hline $\mathrm{D}_{\mathrm{AM}}$ & $\mathrm{r}=-0.66^{\mathrm{ns}}$ & $\mathrm{r}=-0.30^{\mathrm{ns}}$ & $\mathrm{r}=0.19^{\mathrm{ns}}$ & $\mathrm{r}=0.43^{\mathrm{ns}}$ \\
\hline $\mathrm{D}_{10}$ & $\mathrm{r}=-0.60^{\mathrm{ns}}$ & $\mathrm{r}=-0.29^{\mathrm{ns}}$ & $\mathrm{r}=0.03^{\mathrm{ns}}$ & $\mathrm{r}=0.38^{\mathrm{ns}}$ \\
\hline $\mathrm{D}_{15}$ & $\mathrm{r}=-0.43^{\mathrm{ns}}$ & $\mathrm{r}=-0.18^{\mathrm{ns}}$ & $\mathrm{r}=0.08^{\mathrm{ns}}$ & $\mathrm{r}=0.47^{\mathrm{ns}}$ \\
\hline $\mathrm{D}_{20}$ & $\mathrm{r}=-0.46^{\mathrm{ns}}$ & $\mathrm{r}=-0.15^{\mathrm{ns}}$ & $\mathrm{r}=0.36^{\mathrm{ns}}$ & $\mathrm{r}=0.59^{\mathrm{ns}}$ \\
\hline
\end{tabular}

$\mathrm{ns}=$ no significant coefficient $(\mathrm{p}<0.05)$.

Table 3. Annual input of N, P and K via total litterfall in Mabea fistulifera and Eucalyptus urograndis plantations, Selvíria, MS. $\mathrm{D}_{0}$ : control; $\mathrm{D}_{\mathrm{AM}}$ : mineral fertilizer; $\mathrm{D}_{10}, \mathrm{D}_{15}$ and $\mathrm{D}_{20}: 10,15$ and $20 \mathrm{Mg} \mathrm{ha}^{-1}$ of industrial residue from pulp production, respectively.

\begin{tabular}{|c|c|c|c|c|c|c|}
\hline \multirow{3}{*}{ Treatment } & \multicolumn{3}{|c|}{ Mabea fistulifera } & \multicolumn{3}{|c|}{ Eucalyptus urograndis } \\
\hline & $\mathbf{N}$ & $\mathbf{P}$ & $\mathbf{K}$ & $\mathbf{N}$ & $\mathbf{P}$ & $\mathbf{K}$ \\
\hline & \multicolumn{6}{|c|}{ 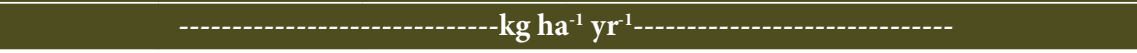 } \\
\hline $\mathrm{D}_{\mathrm{AM}}$ & $20.30 \mathrm{Ba}$ & $1.40 \mathrm{Aa}$ & $14.69 \mathrm{Aa}$ & $17.09 \mathrm{Aa}$ & $1.40 \mathrm{Aa}$ & $16.60 \mathrm{Aa}$ \\
\hline $\mathrm{D}_{0}$ & $10.55 \mathrm{Ac}$ & $0.69 \mathrm{Ab}$ & $6.80 \mathrm{Ab}$ & $10.21 \mathrm{Ab}$ & $0.62 \mathrm{Ab}$ & $6.01 \mathrm{Ac}$ \\
\hline $\mathrm{D}_{10}$ & $12.96 \mathrm{Ab}$ & $0.86 \mathrm{Bb}$ & $7.08 \mathrm{Bb}$ & 15.13 Aa & $1.58 \mathrm{Aa}$ & 13.50 Aa \\
\hline $\mathrm{D}_{15}$ & $9.57 \mathrm{Bc}$ & $0.78 \mathrm{Ab}$ & $5.57 \mathrm{Bb}$ & $12.65 \mathrm{Ab}$ & $0.81 \mathrm{Ab}$ & $9.06 \mathrm{Ab}$ \\
\hline $\mathrm{D}_{20}$ & $9.25 \mathrm{Bc}$ & $1.28 \mathrm{Aa}$ & $5.35 \mathrm{Bb}$ & $14.82 \mathrm{Aa}$ & $1.04 \mathrm{Ab}$ & $9.95 \mathrm{Ab}$ \\
\hline $\mathrm{CV}^{1}(\%)$ & 5.99 & 17.43 & 14.22 & 5.99 & 17.43 & 14.22 \\
\hline $\mathrm{CV}^{2}(\%)$ & 7.95 & 16.36 & 10.43 & 7.95 & 16.36 & 10.43 \\
\hline
\end{tabular}

Means followed by the same capital letter in the lines and lower-case letter in the columns do not differ by Scott-Knott test $(\mathrm{P}<0.05)$.

$\mathrm{CV}^{1}$ : Coefficient of variation among treatments; $\mathrm{CV}^{2}$ : Coefficient of variation between species. 
Eucalyptus urograndis plantation, the input of N, P and K ranged from $10.21\left(\mathrm{D}_{0}\right)$ to $17.09\left(\mathrm{D}_{\mathrm{AM}}\right)$, from $0.62\left(\mathrm{D}_{0}\right)$ to $1.58\left(\mathrm{D}_{10}\right)$ and from $6.01\left(\mathrm{D}_{0}\right)$ to $16.60\left(\mathrm{D}_{\mathrm{AM}}\right) \mathrm{kg} \mathrm{ha}^{-1} \mathrm{yr}^{-1}$, respectively. Thus, the average annual input of $\mathrm{N}, \mathrm{P}$ and $\mathrm{K}$ were $12.53,1.00$ and $7.89 \mathrm{~kg} \mathrm{ha}^{-1} \mathrm{yr}^{-1}$, respectively, in the Mabea fistulifera plantation. On the other hand, the average annual input of $\mathrm{N}, \mathrm{P}$ and $\mathrm{K}$ were 13.98, 1.09 and $11.02 \mathrm{ha}^{-1} \mathrm{yr}^{-1}$, respectively, in the plantation of Eucalyptus urograndis.

In both plantations, the average annual input of $\mathrm{P}$ was relatively higher than that observed in plantations of Eucalyptus camaldulensis and Eucalyptus pellita (0.89 and $0.86 \mathrm{ha}^{-1} \mathrm{yr}^{-1}$, respectively), but lower than in the Eucalyptus urograndis plantation (1.33 $\mathrm{ha}^{-1} \mathrm{yr}^{-1}$ ) in Campos dos Goytacazes, Rio de Janeiro (Zaia \& Gama-Rodrigues, 2004). In general, the input of nutrients by the total litterfall in Eucalyptus urograndis was higher compared to the litterfall of Mabea fistulifera, considering the average values in the fertilization treatments (Table 3).

In general, $\mathrm{D}_{\mathrm{AM}}$ provided higher annual input of $\mathrm{N}, \mathrm{P}$ and $\mathrm{K}$ via total litterfall in the Mabea fistulifera plantation, and there were no significant differences among $\mathrm{D}_{0}, \mathrm{D}_{10}, \mathrm{D}_{15}$ and $\mathrm{D}_{20}$ (Table 3 ). Although $\mathrm{D}_{\mathrm{AM}}$ had also influenced higher input of nutrients in the plantation of Eucalyptus urograndis, there was no significant difference between this treatment and $\mathrm{D}_{10}$, which were both higher than $\mathrm{D}_{0}, \mathrm{D}_{15}$ and $\mathrm{D}_{20}$.

The present study indicated that there was no difference among all of the fertilization treatments with respect to the influence on total annual litterfall. On the other hand, the $\mathrm{D}_{\mathrm{AM}}$ treatment resulted in significant increases in the annual input of nutrients via total litterfall in the case of both tree species, when compared to $\mathrm{D}_{0}$ and the three different doses of industrial residue $\left(\mathrm{D}_{10}, \mathrm{D}_{15}\right.$ and $\left.\mathrm{D}_{20}\right)$. In addition, comparing the different doses of the industrial residue to each other $\left(\mathrm{D}_{10}, \mathrm{D}_{15}\right.$ and $\left.\mathrm{D}_{20}\right)$, the $\mathrm{D}_{10}$ influenced higher input of $\mathrm{N}$ via total litterfall in the Mabea fistulifera plantation, as it did in terms of the input of $\mathrm{N}, \mathrm{P}$ and $\mathrm{K}$ in the Eucalyptus urograndis plantation.

Therefore, the application of $10 \mathrm{Mg} \mathrm{ha}^{-1}$ of industrial residue from pulp production in the row of both Mabea fistulifera and Eucalyptus urograndis plantations was the most promising dose for recovery of the degraded areas studied. This result is consistent with a previous work that indicated that the application of this dose in the row of Eucalyptus urograndis plantation presented a total cost of $\mathrm{R} \$ 4,267.86 \mathrm{ha}^{-1}$ (Arruda et al., 2011). According to these authors, this cost included the purchase of residue, manual and mechanized operations, which was lower when compared to the doses of 15 and $20 \mathrm{Mg} \mathrm{ha}^{-1}$, whose costs were $\mathrm{R} \$ 4,879.90 \mathrm{ha}^{-1}$ and $\mathrm{R} \$ 5,472.33 \mathrm{ha}^{-1}$, respectively.

In addition, the forest species showed different patterns of annual input of nutrients, which was higher in the Eucalyptus urograndis plantation. In terms of total litterfall seasonality, Mabea fistulifera (higher litter production in the dry season) and Eucalyptus urograndis (higher in the rainy season) can be considered complementary. Thus, the plantation of the two forest species in consortium could provide well distributed litterfall throughout the year.

\section{CONCLUSIONS}

There was no difference among the fertilization treatments and between forest species with respect to the total annual litterfall.

The mineral fertilizer provided higher litter input of nutrients, followed by the dose of $10 \mathrm{Mg} \mathrm{ha}^{-1}$ of industrial residue from pulp production for both Mabea fistulifera and Eucalyptus urograndis.

The annual input of nutrients via total litterfall of Eucalyptus urograndis was higher in comparison to the litter of Mabea fistulifera.

\section{SUBMISSION STATUS}

Received: 23 aug., 2016

Accepted: 28 aug., 2016

\section{CORRESPONDENCE TO}

\section{Marcos Gervasio Pereira}

Departamento de Solos, Universidade Federal

Rural do Rio de Janeiro - UFRRJ

BR 465, Km 7, CEP 23890-000, Seropédica, RJ, Brazil

e-mail: mgervasiopereira01@gmail.com

\section{REFERENCES}

Alves MC, Souza ZM. Recuperação do subsolo em área de empréstimo usada para construção de hidrelétrica. 
Revista Ciência Agronômica 2011; 42(2): 301-309. http:// dx.doi.org/10.1590/S1806-66902011000200007.

Arruda OG, Tarsitano MAA, Alves MC, Giácomo RG. Comparação de custos de implantação de eucalipto com resíduo celulósico em substituição ao fertilizante mineral. Revista Ceres 2011; 58: 576-583.

Bellote AFJ, Silva HD, Ferreira CA, Andrade GC. Resíduos da indústria de celulose em plantios florestais. Boletim de Pesquisa Florestal 1998; 37: 99-106.

Cianciaruso MV, Pires JSR, Delitti WBC, Silva EFLP. Produção de serapilheira e decomposição do material foliar em um cerradão da Estação Ecológica de Jataí, município de Luiz Antônio, SP, Brasil. Acta Botanica Brasílica 2006; 20(1): 49-59. http://dx.doi.org/10.1590/ S0102-33062006000100006.

Colodro G. Recuperação de solo de área de empréstimo com lodo de esgoto [tese]. Campinas: Universidade Estadual de Campinas; 2005.

Empresa Brasileira de Pesquisa Agropecuária - EMBRAPA. Centro Nacional de Pesquisa de Solos. Sistema brasileiro de classificação de solos. 2. ed. Rio de Janeiro: EMBRAPA; 2006. 286 p.

Facelli JM, Pickett STA. Plant litter: its dynamics and effects on plant community structure. Botanical Review 1991; 57(1): 1-32. http://dx.doi.org/10.1007/BF02858763.

Ferraz AV. Ciclagem de nutrientes e metais pesados em plantios de Eucalyptus grandis adubados com lodos de esgoto produzidos em diferentes estações de tratamento da região metropolitana de São Paulo [dissertação]. Piracicaba: Universidade de São Paulo; 2009.

Ferreira CA, Silva HD, Andrade GC, Bellote AFJ, Moro L. Deposição de material orgânico e nutrientes em plantios de Eucalyptus grandis em diferentes regimes de adubação. Boletim de Pesquisa Florestal 2001; 43: 75-86.

Ferreira DF. SISVAR: um programa para análises e ensino de estatística. Revista Symposium 2008; 6(2): 36-41.

Figueiredo A Fo, Moraes GF, Schaaf LB, Figueiredo DJ. Avaliação estacional da deposição de serapilheira em uma Floresta Ombrófila mista localizada no Sul do estado do Paraná. Ciência Florestal 2003; 13(1): 11-18.

Giácomo RG, Pereira MG, Machado DL. Aporte e decomposição de serapilheira em áreas de cerradão e mata mesofítica na Estação Ecológica de Pirapitinga MG. Ciência Florestal 2012; 22(4): 669-680. http://dx.doi. org/10.5902/198050987549.

Giácomo RG. Recuperação do solo usando composto produzido com resíduo da extração de celulose [tese]. Ilha Solteira: Universidade Estadual Paulista; 2013.

Guedes MC. Ciclagem de nutrientes após aplicação de lodo de esgoto (biossólido) sobre Latossolo cultivado com Eucalyptus grandis [tese]. Piracicaba: Universidade de São Paulo; 2005.
Hammer $\emptyset$, Harper DAT, Ryan PD. PAST: Paleontological statistics software package for education and data analysis. Palaeontologia Electronica [online]. 2001 [cited $2015 \mathrm{Nov}$ 13]; 4: 1-9. Available from: http://palaeo-electronica. org/2001_1/past/issue1_01.htm

Heaney A, Proctor J. Chemical elements in litter in forests on Volcán Barva, Costa Rica. In: Proctor J, editor. Mineral nutrients in tropical forest and savanna ecosystems. London: British Ecological Society; 1989. p. 255-272.

Klumpp A. Utilização de bioindicadores de poluição em condições temperadas e tropicais. In: Maia NB, Martos HL, Barrella W, editors. Indicadores ambientais: conceitos e aplicações. São Paulo: EDUC; COMPED; INEP; 2001. p. 77-94.

Köppen W. Climatologia: con un estudio de los climas de la tierra. México: Fondo de Cultura Econômica; 1948. 488 p.

Li X, Niu J, Xie B. The effect of leaf litter cover on surface runoff and soil erosion in Northern China. PLoS One 2014; 9(9): 1-15. PMid:25232858

Lopes MIS, Domingos M, Struffaldi-de-Vuono Y. Ciclagem de nutrientes minerais. In: Sylvestre LS, Rosa MMT. Manual metodológico para estudos botânicos na Mata Atlântica. Seropédica: EDUR; UFRRJ; 2002. p. 72-102.

Maciel TMS, Alves MC, Silva FC. Atributos químicos da solução e do solo após aplicação de resíduo da extração de celulose. Revista Brasileira de Engenharia Agrícola e Ambiental 2015; 19(1): 84-90. http://dx.doi.org/10.1590/18071929/agriambi.v19n1p84-90.

Martins SV, Rodrigues RR. Produção de serrapilheira em clareiras de uma floresta estacional semidecidual no município de Campinas, SP. Revista Brasileira de Botanica. 1999; 22(3): 405-412. http://dx.doi.org/10.1590/S010084041999000300009.

Martius C, Höfer H, Garcia MVB, Römbke J, Hanagarth W. Litterfall, litter stocks and decomposition rates in rainforest and agroforestry sites in central Amazonia. Nutrient Cycling in Agroecosystems 2004; 68(2): 137-154. http://dx.doi.org/10.1023/B:FRES.0000017468.76807.50.

Molofsky J, Augspurger CK. The effect of litter on early seedling establishment in a tropical forest. Ecology 1992; 73(1): 68-77. http://dx.doi.org/10.2307/1938721.

Parrotta JA. Influence of overstory composition on understory colonization by native species in plantations on a degraded tropical site. Journal of Vegetation Science 1995; 6(5): 627-636. http://dx.doi.org/10.2307/3236433.

Pimentel-Gomes F. Curso de estatística experimental. 13. ed. Piracicaba: Nobel; 1990. 468 p.

Portes MCGO, Koehler A, Galvão F. Variação sazonal de deposição de serapilheira em uma Floresta Ombrófila Densa Alto Montana no morro do Anhagava - PR. Floresta 1996; 26(1-2): 3-10.

Scheer MB, Gatti G, Wisniewski C, Mocochinski AY, Cavassani AT, Lorenzetto A et al. Patterns of litter production 
in a secondary alluvial Atlantic Rain Forest in southern Brazil. Brazilian Journal of Botany 2009; 32(4): 805-817. http://dx.doi.org/10.1590/S0100-84042009000400018.

Schumacher MV, Brun LJ, Hernandes JI, König FG. Produção de serapilheira em uma floresta de Araucaria angustifolia (Bertol.) Kuntze no município de Pinhal Grande-RS. Revista Árvore 2004; 28(1): 29-37. http:// dx.doi.org/10.1590/S0100-67622004000100005.

Schumacher MV, Corrêa RS, Viera M, Araújo EF. Produção e decomposição de serapilheira em um povoamento de Eucalyptus urophylla x Eucalyptus globulus maidenii. Cerne 2013; 19(3): 501-508. http://dx.doi.org/10.1590/ S0104-77602013000300018.

Scoriza RN, Piña-Rodrigues FCM. Influência da precipitação e temperatura do ar na produção de serapilheira em trecho de Floresta Estacional em Sorocaba, SP. Floresta 2014; 44(4): 687-696. http://dx.doi.org/10.5380/rf.v44i4.34274.

Silva CJ, Lobo FA, Bleich ME, Sanches L. Contribuição de folhas na formação da serrapilheira e no retorno de nutrientes em floresta de transição no norte de Mato Grosso. Acta Amazonica 2009; 39(3): 591-600. http:// dx.doi.org/10.1590/S0044-59672009000300014.

Silva PHM, Poggiani F, Lima WP, Libardi PL. Soil water dynamics and litter production in eucalypt and native vegetation in southeastern Brazil. Scientia Agricola 2014;
71(5): 345-355. http://dx.doi.org/10.1590/0103-90162013-0325.

Souza JA, Davide AC. Deposição de serrapilheira e nutrientes em uma mata não minerada e em plantações de bracatinga (Mimosa scabrella) e de eucalipto (Eucalyptus saligna) em áreas de mineração de bauxita. Cerne 2001; 7(1): 101-113.

Tedesco MJ, Gianello C, Bissani CA, Bohnen H, Volkweiss SJ. Análise de solo, plantas e outros materiais. 2. ed. Porto Alegre: Universidade Federal do Rio Grande do Sul; 1995. 174 p. Boletim Técnico n. 5.

Universidade Estadual Paulista - UNESP. Canal clima [online]. 2016. [cited 2016 Jan 15]. Available from: http:// clima.feis.unesp.br/administra_clima.php

Valcarcel R, Silva ZS. A eficiência conservacionista de medidas de recuperação de áreas degradadas: proposta metodológica. Revista Floresta 2000; 27(1-2): 101-114.

Vitousek PM, Sanford RL Jr. Nutrient cycling in moist tropical forest. Annual Review of Ecology and Systematics 1986; 17(1): 137-167. http://dx.doi.org/10.1146/annurev. es.17.110186.001033.

Zaia FC, Gama-Rodrigues AC. Ciclagem e balanço de nutrientes em povoamentos de eucalipto na região norte fluminense. Revista Brasileira de Ciencia do Solo 2004; 28(5): 843-852. http://dx.doi.org/10.1590/S010006832004000500007 . 